\title{
A study on the usage and relevance of mobile wallets in India in COVID-19 pandemic
}

\author{
Anjana George, Chafekali Sonawane, Disha Mishra
}

Department of Accountancy, Symbiosis College of Arts and Commerce, Pune, Maharashtra, India

\begin{abstract}
Purpose: The use of mobile wallets in India was on a rise from the past few years on account of its various advantages
such as ease of use, simplicity, convenience, and cost-effectiveness. However, it was during the COVID-19 pandemic
in 2020, that the usage of mobile wallets increased drastically. People who were hesitant in using e-wallets till then
saw no choice but to switch their mode of payment due to quarantine restrictions placed across the nation. Customers
who converted to e-wallets during this time saw its advantages first hand and now are reluctant to go back to their
previous modes of payment, primarily cash. This research paper studies the reasons for the increasing popularity and
use of mobile payment apps in India during the COVID-19 pandemic in 2020, and whether this surge will continue
to sustain even after the pandemic. Research Methodology: The three most popular payment apps used in India,
namely, Google Pay, PhonePe, and Paytm are considered for this study. The population of the research study are users
of mobile wallets in India. The researchers have chosen "Convenience Sampling Method" to collect the relevant data
by circulating the questionnaire link through social media to receive responses. A sample of 120 responses have been
selected and analyzed for the research study. Findings: The results of the study revealed that, since 2020, people have
been increasing their usage of mobile wallets significantly and will continue to do so in the future. Implications: The
results clearly indicated that the usage of mobile wallets will continue to sustain even after the COVID-19 pandemic,
although new techniques will need to be designed and deployed to keep this surge going. Originality: The research
is based on a self-formulated methodology. All the references are duly cited and all the information are collected by
the researchers on their own.
Keywords: Cashless payment, digital payment, mobile wallet, payment apps
JEL Classifications: E42 - Payment Systems
\end{abstract}
\section{INTRODUCTION}

Digital payment, as contrast to traditional cash payments, is a type of payment that is done through digital methods. Both the payer and the payee send and receive money using digital ways in digital payments. Electronic payment is another name for it. Since its introduction, the platform has grown strongly and adapted to handle large volumes.
A digital wallet, also known as e-wallet, is an electronic device, online service, or software program that allows one party to make electronic transactions with another party bartering digital currency units for goods and services. There are many apps serving as a digital wallet in India including PhonePe, Google Pay, Paytm, and Amazon Pay.

Digital payment was introduced in India with the vision of a cashless economy. The Digital India program is a

\section{*Corresponding author:}

Anjana George, Symbiosis College of Arts and Commerce, Pune, Maharashtra, India. E-mail: anjanageorg@gmail.com

Received: 28 July, 2021, Accepted: 15 September, 2021

DOI: $10.18843 / \mathrm{ijcms} / \mathrm{v} 12 \mathrm{i} 3 / 01$ 
flagship program of the Government of India with a vision to transform India into a digitally empowered society and knowledge economy. "Faceless, Paperless, Cashless" is one of professed roles of Digital India. As part of promoting cashless transactions and converting India into a less cash society, various modes of digital payments are available. One among them being mobile wallets.

During the COVID-19 pandemic, the digital payment system saw an increase in its usage like never before. All the payment apps reported an increase in the number of users, volume of transactions, and daily limits utilized. It was during this time that mobile wallets and other forms of digital payments became a necessity, rather than a luxury that many were reluctant to use. Indians have the mentality of remaining traditional as long as they can before they make a switch for convenience. This is seen in the usage of mobile wallets too. It is the youth which primarily uses electronic wallets, and the other age groups are yet to catch on.

It was during the demonetization in 2016 and the COVID19 pandemic in 2020 that people who were reluctant to switch or people who rarely used such wallets made the switch, and many have permanently switched due to its convenience. It says that it takes 21 days to form a habit, and surely, the year-long lockdown in 2020 has made the usage of mobile wallets a habit for many users who now find it difficult to switch back.

There are different apps available that allow users to make payments online. These are very convenient to use and provide flexibility to the users as they allow users to make payments anytime and from anywhere. Some of the apps used for online payments are as follows: PhonePe, Google Pay, and Paytm.

PhonePe, headquartered in Bengaluru, is a digital wallet company and is the first app built on Unified Payment Interface (UPI). It is a UPI-based app that allows users to make transactions using PhonePe wallet, credit/debit card, or UPI. This app allows one to pay utility bills, do recharges, and transfer money. PhonePe is accepted as a payment option at over 17.5 million offline and online merchant outlets across 500 cities in India covering food, travel, groceries, medicines, movie tickets, etc. It currently has over 280 million users. The company launched the PhonePe ATM in January 2020. The PhonePe ATM allows neighborhood Kirana stores to dispense cash in real time to customers.

Paytm has its headquarters in Noida, UP. It is available in 11 languages. One extra feature added in this app is that the users can receive cashback in the form of gold through its "PhonePe Gold Offer." Paytm also provides banking facility in the form of Paytm Payment Bank in which an account can be opened without any charges. A user can deposit an amount of 1 lakh in this account and an interest of $3.5 \%$ can also be earned on that amount. According to Times of India, the shareholders of Paytm have approved the largest IPO the country has ever seen, a whopping Rs. 16,600 crore (PTI, 2021).

Google Pay (GPay) is a digital wallet platform and online payment system developed by Google to power in-app, online, and in-person contactless purchases on mobile devices, enabling users to make payments with smartphones, tablets, or watches. In India, Google Pay allows transactions using UPI only. There is no wallet facility and the app is directly linked to the bank account. A user can also earn Rs. 51 by inviting a friend and making him do any transactions using your reference link. Furthermore, the first transaction using this app provides the user with some amount of scratch cards. It is the most popular app among the Indian youth because of its simplicity.

This study focuses on the usage and relevance of mobile wallets, specifically PhonePe, Paytm, and GPay, in India during the COVID-19 pandemic. The objectives of the research include the examination of the relevance and popularity of mobile wallets in India during the COVID-19 and analyze the reasons for the increase in users and usage of mobile wallets in India during the pandemic. The study will also analyze whether the usage of mobile wallets will continue to sustain even after the pandemic in India.

\section{Need for the Study}

This study helps understand the reasons for the increase in popularity of mobile wallets during the COVID-19 pandemic and helps to analyze the factors affecting it. Many users of mobile wallets during the COVID-19 pandemic made the switch due to necessary reasons. During this time, mobile wallets became a necessity rather than a luxury.

This study focuses on the utility of mobile wallets during this time and also examines whether the popularity and usage attained during this time, will continue even after the pandemic or not.

\section{REVIEW OF LITERATURE}

During the COVID-19 pandemic, the digital payment system saw an unprecedented growth in its usage. All the 
payment apps reported an increase in the number of users, volume of transactions, and daily limits utilized. It was during this time that mobile wallets and other forms of digital payments became a necessity, rather than a luxury that many were reluctant to use. Indians have the philosophy of holding on to their traditions for as long as possible before making a change for the sake of convenience. This can also be seen in the use of mobile wallets. Many consumers have become accustomed to using mobile wallets as a result of the year-long lockdown in 2020, and switching back has become difficult.

Prior study has revealed that the use of these apps for making online payments has increased dramatically in recent years, particularly following India's demonetization in 2016 (Praiseye and John, 2018). The number of users using these apps is increasing significantly day by day. The wallet facility of these apps attracts a lot of users. The authors analyzed that among the three most popular payment apps used in India, namely, Google Pay, PhonePe, and Paytm, Google Pay is highly preferred for making high-value transactions as it makes payment directly from the bank account as compared to other apps (Gupta et al., 2020). The study also suggested that more security features need to be added to increase the user base further in future.

However, even after demonetization, when fresh currency notes began to circulate in the markets and the economy began to stabilize, individuals reverted to cash to resume transactions. Demonetization did not retain many mobile wallet users, since the number of users fell following this period. Mobile wallets also faced significant changes in security compliances and access throughout this period. Everyone had a smartphone, but there was a need to create awareness and acceptance about the mobile wallet services which are comfortable, very secure, confidential, safe, and convenient without any effort and interruption (Vijai, 2019).

Studies have shown that M-wallets are rapidly becoming the mode of mainstream online payment. Shoppers are adopting mobile wallets at an incredibly prolific pace, mainly because of ease of use and convenience. Especially shoppers who are Tech-savvy are demanding omni channel, seamless retail experiences increasingly and seek solutions that deliver this. It can be concluded that there will be a tremendous growth in adoption of mobile wallets in the forthcoming years (Kotecha, 2018).

Most importantly, studies have shown that during the COVID-19 outbreak where people were encouraged to keep up with the public sphere, there has been an increase in orders placed on ecommerce websites and apps for food, entertainment, and food. Someone who performs any such services on E-commerce platforms can pay through the payment gateway (Jain et al., 2020).

Studies undertaken also concluded that the COVID-19 pandemic has changed the whole way of living and the impact of the same is visible on online payment systems. Contactless payments, safety, fast settlements, userfriendly OS, and rewards are some of the factors which have promoted the use of online payment systems in India. During lockdown, online payment systems have really helped the people in transacting without fear of getting contacted with other infected people (Anandan and Mouli, 2020), which was the most dominant reason.

Since the onset of the COVID-19 pandemic, digital payment providers such as PhonePe, Paytm, Amazon Pay, and others have experienced almost a $50 \%$ increase in transactions through their digital wallets (Bhalla, 2020). COVID-19 hampered many sectors during the quarantine restrictions placed in India, but it was during this time that digital payment apps and Fintech Systems got the boost they needed in the still cash dominant India (Surabhi, 2020). In November, Google Pay and PhonePe had a combined market share of over $82 \%$ by volume and over $86 \%$ by value among the main UPI providers (Soni, 2021). Meanwhile, Paytm got its biggest boost ever, when their shareholders approved the country's biggest public offer plan of Rs/16,600 crores in 2021 (PTI, 2021).

This study focuses on examining the reasons for the popularity and usage of mobile wallets during the COVID19 pandemic and examines the reasons for the same. This research will provide suitable insights into businesses in formulating their future strategies to sustain the increase in users even after the COVID-19 pandemic.

\section{Research Problem}

During the COVID-19 pandemic, many users of mobile wallets made the switch due to necessary reasons. During this time, mobile wallets became a necessity rather than a luxury. However, this switch may not sustain after the pandemic, and so this research study focuses on the problem of whether the popularity and usage gained by these apps during this time will continue even after the pandemic or not.

These companies adapted quickly to the surge in usage during the pandemic, but need to strategize for the post-pandemic 
period and for what comes in the future. The reasons for the surge need to be studied and targeted during planning and strategy to earn future benefits, and to sustain the surge.

\section{Objectives of the Study}

The objectives of the study were as follows:

1. To examine the relevance and popularity of mobile wallets in India during the COVID-19 pandemic

2. To analyze and examine the reasons for the increase in users and usage of mobile wallets in India during the pandemic

3. To analyze whether the usage of mobile wallets will continue to sustain even after the pandemic in India.

\section{Hypothesis of the Study}

$\mathrm{H}_{1}$ : The COVID-19 pandemic has resulted in an increase in the usage of mobile wallets in India.

$\mathrm{H}_{2}$ : The increase in usage of mobile apps in India will continue to sustain even after the COVID-19 pandemic.

\section{Working Definitions of the Terms Used}

\begin{tabular}{|c|c|c|}
\hline Terms & Working definition & $\begin{array}{l}\text { Related } \\
\text { terms }\end{array}$ \\
\hline Pandemic & $\begin{array}{l}\text { COVID-19 pandemic } \\
\text { which affected India } \\
\text { in 2019-2020 }\end{array}$ & $\begin{array}{l}\text { Widespread, } \\
\text { global }\end{array}$ \\
\hline E-wallet & $\begin{array}{l}\text { An electronic card } \\
\text { used for transaction } \\
\text { made online through } \\
\text { smartphone or } \\
\text { computer }\end{array}$ & $\begin{array}{l}\text { Google Pay, } \\
\text { Phone Pay, } \\
\text { Paytm }\end{array}$ \\
\hline User & $\begin{array}{l}\text { An individual or } \\
\text { group who use } \\
\text { mobile wallets in } \\
\text { India }\end{array}$ & $\begin{array}{l}\text { Students, } \\
\text { senior citizen, } \\
\text { customers, } \\
\text { party, etc. }\end{array}$ \\
\hline Digital payment & $\begin{array}{l}\text { Payments that } \\
\text { are done online } \\
\text { through the internet } \\
\text { or mobile-enabled } \\
\text { services }\end{array}$ & $\begin{array}{l}\text { Electronic, } \\
\text { payment } \\
\text { mode }\end{array}$ \\
\hline Cashless & $\begin{array}{l}\text { Payments are made } \\
\text { using cards or } \\
\text { electronic methods } \\
\text { rather than physical } \\
\text { money }\end{array}$ & $\begin{array}{l}\text { Digital, } \\
\text { computerized, } \\
\text { online, } \\
\text { electronic }\end{array}$ \\
\hline
\end{tabular}

\begin{tabular}{|c|c|c|}
\hline Transaction & $\begin{array}{l}\text { An exchange or } \\
\text { transfer of funds } \\
\text { using e-wallets }\end{array}$ & $\begin{array}{l}\text { Funds, } \\
\text { outreach, } \\
\text { transfer }\end{array}$ \\
\hline Cashback & $\begin{array}{l}\text { An amount of money } \\
\text { offered after offered } \\
\text { in return as reward } \\
\text { for immediate } \\
\text { payment }\end{array}$ & $\begin{array}{l}\text { Incentive, } \\
\text { reward, } \\
\text { discount, } \\
\text { refund }\end{array}$ \\
\hline Relevance & $\begin{array}{l}\text { Significance of using } \\
\text { e-wallets in India }\end{array}$ & $\begin{array}{l}\text { Applicability, } \\
\text { importance, } \\
\text { purpose, need }\end{array}$ \\
\hline Payments & $\begin{array}{l}\text { The act of paying a } \\
\text { sum of money using } \\
\text { wallets in India }\end{array}$ & $\begin{array}{l}\text { Settlement, } \\
\text { deposit, } \\
\text { transfers }\end{array}$ \\
\hline Demonetization & $\begin{array}{l}\text { An act of stripping } \\
\text { the legal tender } \\
\text { status of currency } \\
\text { units in India in the } \\
\text { year } 2016\end{array}$ & $\begin{array}{l}\text { Terminate, } \\
\text { ending, break }\end{array}$ \\
\hline Popularity & $\begin{array}{l}\text { The state of being } \\
\text { used more by many }\end{array}$ & $\begin{array}{l}\text { Supported, } \\
\text { used, liked }\end{array}$ \\
\hline
\end{tabular}

\section{Scope of the Research Study}

The study is based on the Indian users of e-wallets during COVID-19 pandemic in 2020. This research paper studies the reasons for increasing use of e-wallets during the COVID-19 pandemic. In addition, it also examines whether the popularity and usage attained during this period will continue in the future or not.

Indians who are the current users of e-wallets (specifically Paytm, GPay, and Phone Pay) are the respondents of the questionnaire because they have significant information required by this study. The respondents are above 15 years of age and have basic knowledge on how to use these apps. The data were collected from August 1 to 8, 2021.

\section{RESEARCH METHODOLOGY}

\section{Population, Sample, and Sampling Method}

The population of the research study are users of mobile wallets in India, which is an infinite population. The researchers have chosen "Convenience Sampling Method" to collect the relevant data by circulating the questionnaire link through social media to receive responses. A sample of 120 responses have been selected and analyzed for the research study. 


\section{Tools}

\section{Ø Secondary data}

Various parameters and statistics curated for comparison between the three apps (GPay, Paytm, and PhonePe) to study the extent of increase in usage and relevance of mobile wallets during the COVID-19 pandemic in India.

\section{$\varnothing$ Primary data}

Questionnaire on Google Forms - quantitative information to be extracted and analyzed to study the reasons for the increase in users and usage of mobile wallets in India during the pandemic.

\section{Data Collection}

PART A: To study the extent of increase in usage and relevance of mobile wallets during the COVID-19 pandemic in India

\section{Data Analysis and Interpretation}

GPay saw a decline in market share in 2021 due to the enforcement of the new market share rules on UPI for mobile apps by National Payments Corporation of India (NPCI). According to the new rules, digital payment apps have to limit their share in the overall volume of transactions on UPI at 30\% (Manikandan, 2021). This was enforced to curb monopoly. It affected GPay to a great extent, and this disadvantage to GPay proved advantageous to PhonePe. However, on the whole, even GPay witnessed an increase in market share and volume of transactions from 2020 to 2021. GPay's volume of UPI transactions saw a few bumps on the way, but it nearly doubled in a year from April 2020 to June 2021. This growth was definitely due to the impact of the lockdown. The transaction volume and value have apparently scaled up faster during this time as people switched to digital mode to avoid cash usage. GPay even adapted quickly and introduced many new features like the Privacy Toggle Button, which lets users turn off activity in privacy settings (Tech Desk, 2021).

PhonePe, Walmart's payment arm in India, continued to remain the dominant UPI app for a third straight month in February 2021, cornering an impressive $42.5 \%$ share of the 975.53 million UPI transactions. PhonePe was spun off from Flipkart in December last year and currently competes with Google Pay and Paytm primarily. According to the data released by the NPCI, PhonePe registered 1,292.71 million UPI transactions in June 2021. Even though GPay was affected by the new rule of capping the volume of UPI transactions at $30 \%$, enforced by NPCI, PhonePe took advantage of this and rose to the occasion. The decrease in GPay's market share saw a corresponding increase in the market share of PhonePe in 2021. PhonePe introduced many clever features as well during this period to sustain its users like the Auto Top Up feature. Once the wallet balance goes below a certain limit, the app will automatically top up the wallet from the bank account linked to the PhonePe account (Sheth, 2021).

From Table 1, it is quite clear that there was a slight decrease in use of Paytm app at the onset of the lockdown April 2020. To combat this, Paytm continued to innovate and launch various relative services, features, and schemes. Services such as the E-ledger service which is known as "Paytm Business Khata" has become an essential service for ration stores as it automates their manual cash collection and helps to improve cash flow and to clear outstanding digitally (ZeeBiz WebTeam, 2020). Paytm has also launched the "Vaccine Finder" feature on their app to help the users find leads for vaccine booking, including information such as the type of vaccine available and the fee charged (Pakrasi, 2021). Paytm unveiled a great, new feature that allows investors to apply for the IPO before the issue opens in the market, and has started with the shares of Zomato (News18, 2021). Along with these exciting new services, Paytm has offered many more offers and cashback opportunities. With PhonePe's tremendous growth in 2021, Paytm saw a slight decline in the market share from $15.1 \%$ in May 2020 to $14.86 \%$ in June 2021. Paytm has witnessed certain bumps in the road, but on the whole, Paytm witnessed their UPI transactions to triple in a year, during the pandemic.

The use of these apps has made a huge growth during the COVID-19 pandemic. The number of users using these apps is increasing significantly day by day. The wallet facility of these apps (PhonePe and Paytm) attracts a lot of users. According to analysis, among the three apps, PhonePe has increased its market share tremendously during this period and is highly preferred for making high-value transactions. PhonePe has taken a comfortable lead from April 2020 to June 2021 in India's payments market over its rivals GPay and Paytm. However, on the whole, all three apps saw an increase in the transactions within a year, like never before, due to the COVID-19 pandemic.

PART B: To examine the reasons for the increase in users and usage of mobile wallets in India during the pandemic and to analyze whether the usage of mobile wallets will continue to sustain even after the pandemic in India. 
George, et al.: Study on usage and relevance of mobile wallets in India in COVID-19 pandemic

\section{Table 1: Comparison between GPay, PhonePe, and Paytm on various parameters}

\begin{tabular}{|c|c|c|c|c|c|c|}
\hline S. No. & Parameter & Phase & Period & GPay & PhonePe & Paytm \\
\hline \multirow[t]{6}{*}{1.} & \multirow[t]{5}{*}{ UPI Transactions } & \multirow{2}{*}{$\begin{array}{l}\text { Beginning of } \\
\text { COVID-19 } \\
\text { Lockdown }\end{array}$} & April 2020 & 440.06 million & 374.1 million & 128.18 million \\
\hline & & & May 2020 & 547.93 million & 452.58 million & 124.69 million \\
\hline & & \multirow[t]{2}{*}{$\begin{array}{l}\text { After relaxations } \\
\text { were allowed }\end{array}$} & $\begin{array}{l}\text { January } \\
2021\end{array}$ & 853.53 million & 968.72 million & 332.69 million \\
\hline & & & $\begin{array}{l}\text { February } \\
2021\end{array}$ & 827.86 million & 975.53 million & 340.71 million \\
\hline & & Currently & June 2021 & 972.26 million & 1,292.71 million & 383.05 million \\
\hline & $\begin{array}{l}\text { Growth in UPI } \\
\text { transactions }\end{array}$ & 2020-2021 & & $\begin{array}{l}\text { Not a continuous } \\
\text { growth; but nearly } \\
\text { doubled in a year }\end{array}$ & $\begin{array}{l}\text { Continuous } \\
\text { growth; nearly } \\
\text { tripled in a year }\end{array}$ & $\begin{array}{l}\text { Not a continuous } \\
\text { growth; but tripled } \\
\text { in a year }\end{array}$ \\
\hline \multirow[t]{5}{*}{2.} & \multirow[t]{5}{*}{$\begin{array}{l}\text { Value of } \\
\text { transactions }\end{array}$} & \multirow{2}{*}{$\begin{array}{l}\text { Beginning of } \\
\text { COVID-19 } \\
\text { lockdown }\end{array}$} & Apr 2020 & $\begin{array}{l}\text { Rs. } 66,554.28 \\
\text { crores }\end{array}$ & $\begin{array}{l}\text { Rs. } 60,990.48 \\
\text { crores }\end{array}$ & $\begin{array}{l}\text { Rs. } 12,716.78 \\
\text { crores }\end{array}$ \\
\hline & & & May 2020 & $\begin{array}{l}\text { Rs. } 97,014.42 \\
\text { crores }\end{array}$ & $\begin{array}{l}\text { Rs. } 89,954.82 \\
\text { crores }\end{array}$ & $\begin{array}{l}\text { Rs. } 15,675.58 \\
\text { crores }\end{array}$ \\
\hline & & \multirow[t]{2}{*}{$\begin{array}{l}\text { After relaxations } \\
\text { were allowed }\end{array}$} & $\begin{array}{l}\text { January } \\
2021\end{array}$ & $\begin{array}{l}\text { Rs. } 177,791.47 \\
\text { crore }\end{array}$ & $\begin{array}{l}\text { Rs. } 191,973.77 \\
\text { crore }\end{array}$ & $\begin{array}{l}\text { Rs. } 37,845.76 \\
\text { crore }\end{array}$ \\
\hline & & & $\begin{array}{l}\text { February } \\
2021\end{array}$ & $\begin{array}{l}\text { Rs. } 174,455.33 \\
\text { crores }\end{array}$ & $\begin{array}{l}\text { Rs. } 189,517.82 \\
\text { crores }\end{array}$ & $\begin{array}{l}\text { Rs. } 38,493.52 \\
\text { crores }\end{array}$ \\
\hline & & Currently & June 2021 & $\begin{array}{l}\text { Rs. } 207,287.73 \\
\text { crores }\end{array}$ & $\begin{array}{l}\text { Rs. } 262,565.88 \\
\text { crores }\end{array}$ & $\begin{array}{l}\text { Rs. } 44,981.11 \\
\text { crores }\end{array}$ \\
\hline \multirow[t]{3}{*}{3.} & \multirow[t]{2}{*}{ Market share } & $\begin{array}{l}\text { During COVID-19 } \\
\text { lockdown }\end{array}$ & May 2020 & $38.4 \%$ & $19.8 \%$ & $15.1 \%$ \\
\hline & & Currently & $\begin{array}{l}\text { February } \\
2021\end{array}$ & $36.11 \%$ & $42.55 \%$ & $14.86 \%$ \\
\hline & $\begin{array}{l}\text { Growth in market } \\
\text { share }\end{array}$ & $2020-21$ & & Decline & Drastic growth & Decline \\
\hline 4. & Wallet facility & Currently & 2021 & No wallet facility & $\begin{array}{l}\text { Provides wallet } \\
\text { facility }\end{array}$ & $\begin{array}{l}\text { Provides wallet } \\
\text { facility }\end{array}$ \\
\hline 5. & $\begin{array}{l}\text { Cashback and } \\
\text { rewards }\end{array}$ & Currently & 2021 & $\begin{array}{l}\text { Directly added to } \\
\text { the linked bank } \\
\text { account }\end{array}$ & Added to wallet & Added to wallet \\
\hline 6. & Security & Currently & 2021 & More secure & More secure & Less secure \\
\hline 7. & KYC compliance & Currently & 2021 & Not required & Required & Required \\
\hline 8. & Own bank facility & Currently & 2021 & Not provided & Not provided & Provided \\
\hline 9. & $\begin{array}{l}\text { Languages } \\
\text { supported }\end{array}$ & Currently & 2021 & 8 languages & 11 languages & 11 languages \\
\hline 10. & $\begin{array}{l}\text { Any new feature } \\
\text { introduced in } \\
2020 \text { or } 2021\end{array}$ & Currently & 2021 & $\begin{array}{l}\text { Privacy toggle } \\
\text { button }\end{array}$ & $\begin{array}{l}\text { Auto top up } \\
\text { feature }\end{array}$ & $\begin{array}{l}\text { Pre-Open IPO } \\
\text { application; LPG } \\
\text { cylinder booking }\end{array}$ \\
\hline
\end{tabular}

Source: https://www.npci.org.in/what-we-do/upi/upi-ecosystem-statistics

\section{Questionnaire Responses Summarized}

From the responses collected from the questionnaire, the following points were noted about the respondents and their usage of mobile wallets:

\section{Respondent's Portfolio}

1. Age

As shown in Figure 1, majority of the respondents were between the age categories of 20 and 29 , who are 
among the primary users of mobile wallets in India. They constituted about $80 \%$ of the total respondents. This was followed by the respondents belonging to the age group 40-49 and 50+, who comprised 8.3\% and $5.8 \%$, respectively.

2. Gender

The questionnaire was filled by 120 respondents which included responses only from males and females. About $57.5 \%$ of the respondents were male, while the remaining $42.5 \%$ were female, which is clearly indicated in Figure 2.

3. Educational qualifications

As shown in Figure 3, majority of the respondents were graduates or postgraduates comprising $72.5 \%$ and $23.3 \%$, respectively.

4. Occupation

As shown in Figure 4, about 59.2\% the respondents were engaged in some kind of job/profession, and the remaining $40.8 \%$ were currently students.

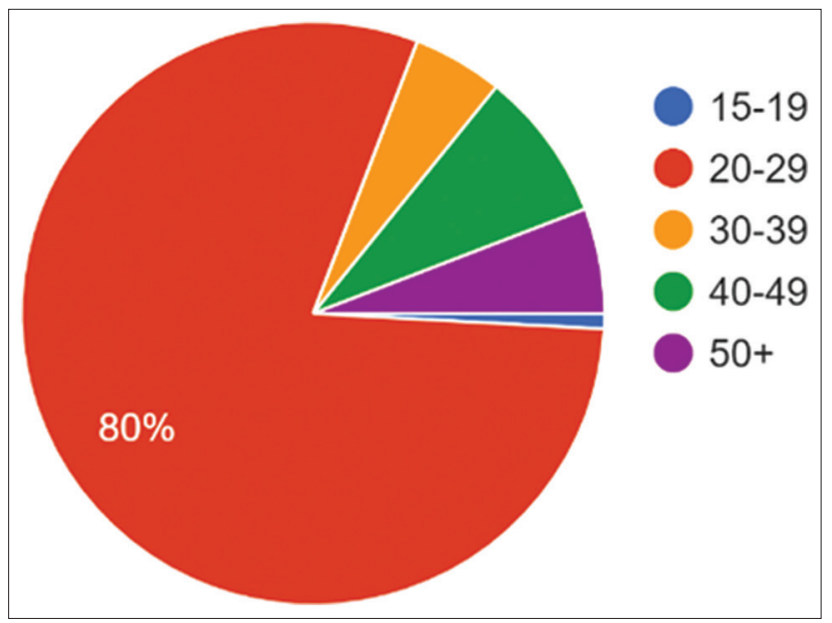

Figure 1: Age of the respondents

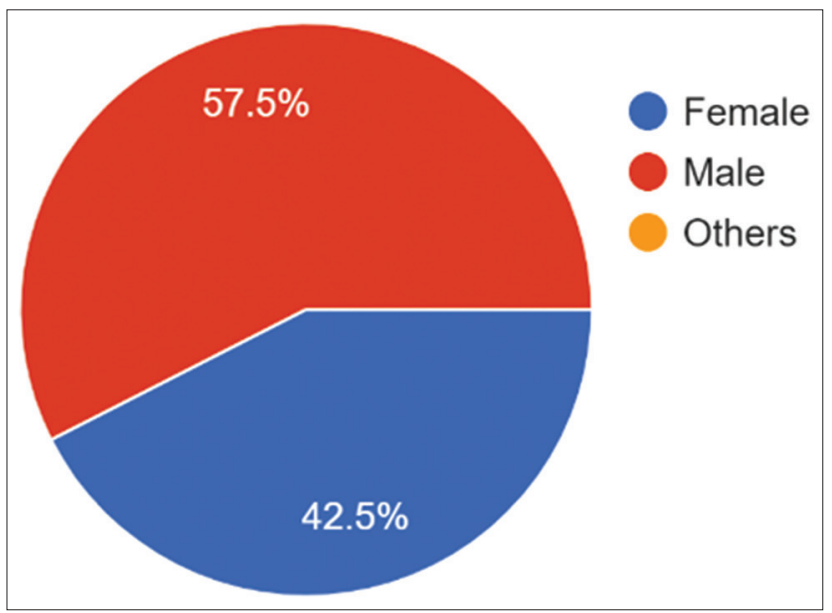

Figure 2: Gender of the respondents

\section{Data Analysis and Interpretation}

5. Usage of smartphones

Smartphones were used by every single one of the respondents, which is easily comprehended from Figure 5. Since mobile wallets can only be used on smartphones, it is critical that our respondents have one.

6. Awareness about mobile wallets

The word "Mobile Wallet" or "E-Wallets" was recognized by $100 \%$ of the respondents as shown in Figure 6. This demonstrates the high degree of awareness about mobile wallets in 2021 .

7. Usage of mobile wallets

Mobile wallets were used by each and every single one of the respondents, which is clearly indicated in Figure 7. This demonstrates the widespread use of mobile wallets in 2021.

8. Preference of mobile wallets

As shown in Figure 8, Google Pay was chosen by $52.55 \%$ of the respondents as their preferred mobile wallet followed by PhonePe with $25.8 \%$ and Paytm with $20.8 \%$. One respondent favored the BHIM app as well.

9. Transactions made during the COVID-19 pandemic Mobile wallets were extremely popular during the COVID-19 pandemic primarily because of its

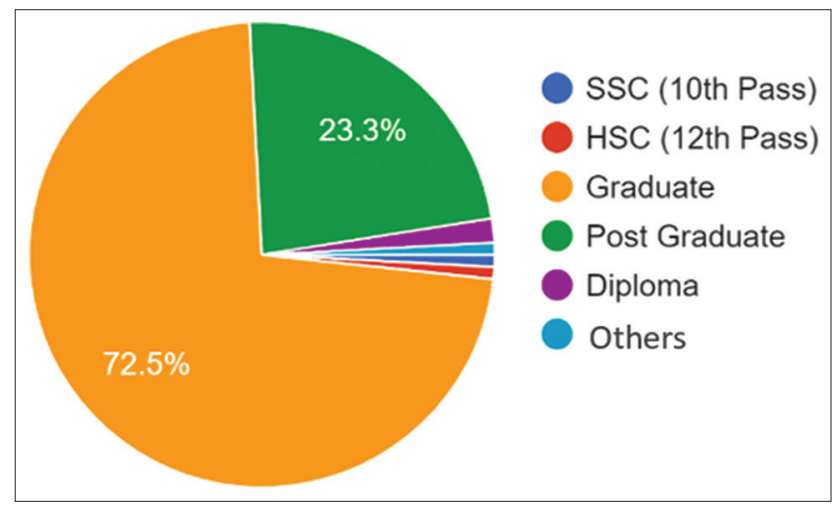

Figure 3: Educational qualifications of the respondents

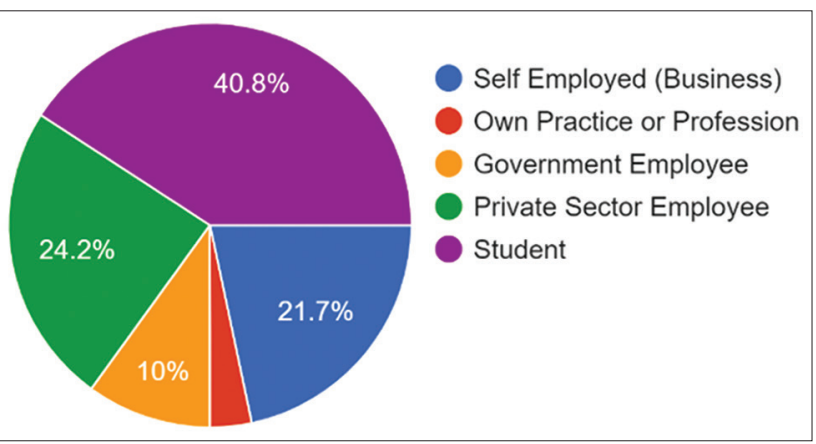

Figure 4: Occupation of the respondents 


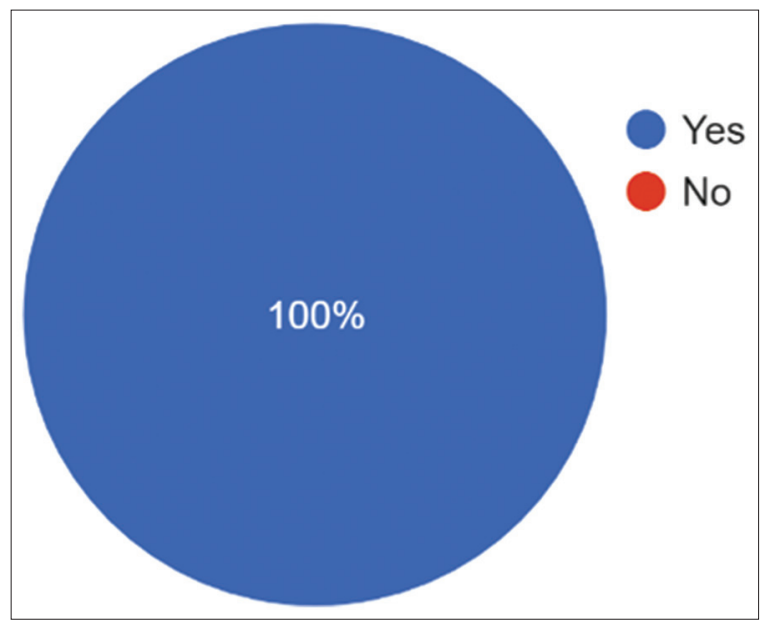

Figure 5: Usage of smartphones

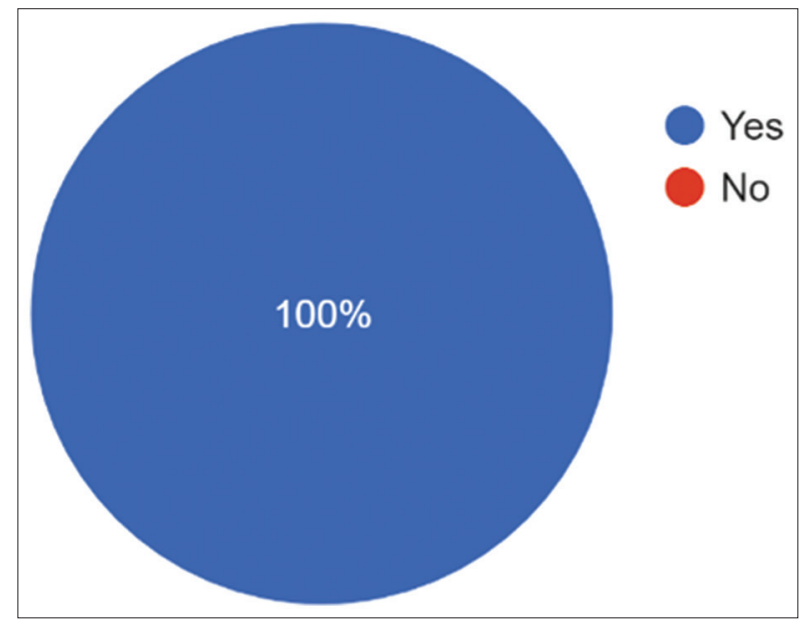

Figure 6: Awareness about mobile wallets

simplicity and convenience. As shown in Figure 9, about $88.3 \%$ of the respondents used mobile wallets to order food, while $85 \%$ of the respondents used it to recharge their mobile phones. Clearly, food and data were consumed the most during the lockdown in India!

10. Reasons for usage of mobile wallets during the COVID-19 pandemic

During the COVID-19 pandemic, the top reasons for using mobile wallets were ease of payment, convenience, and contactless payment, which is clearly indicated in Figure 10. The difficulty to withdraw cash, security, and the discounts and incentives given by the apps were among the other reasons. Throughout 2020, mobile wallets underwent significant modifications to accommodate this surge of usage.

11. Usage of mobile wallets during the lockdown in 2020 As shown in Figure 11, about $40 \%$ of the respondents used mobile wallets more than 5 times in a week,

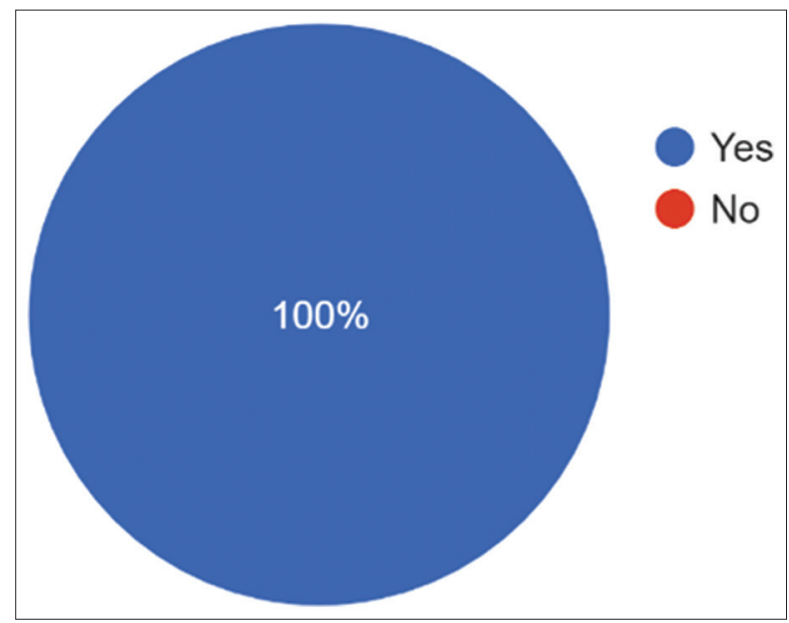

Figure 7: Usage of mobile wallets

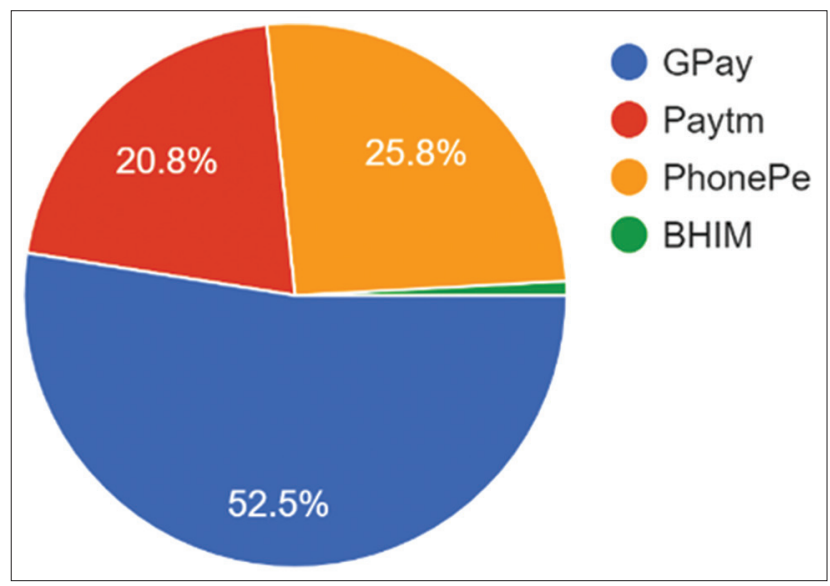

Figure 8: Preference of mobile wallets

while $30.8 \%$ and $29.2 \%$ of the respondents used it 3-5 times and 1-2 times in a week, respectively. This showed the frequency of the usage of mobile wallets, and how crucial these apps were for people during the pandemic.

12. Usage of mobile wallets In 2021:

As shown in Figure 12, the number of respondents used mobile wallets more than 5 times in a week rose from $40 \%$ in 2020 to $47.5 \%$ during 2021 , while $26.7 \%$ and $25.8 \%$ of the respondents used it $3-5$ times and 1-2 times in a week, respectively. This clearly indicates that usage of mobile wallets will continue to sustain even after the COVID-19 pandemic and is increasing day by day.

13. Adaptability of mobile wallets during the COVID-19 pandemic

As shown in Figure 13, about 70.8\% of the respondents were extremely satisfied with the adaptability of the mobile wallets during the COVID-19 pandemic, and 


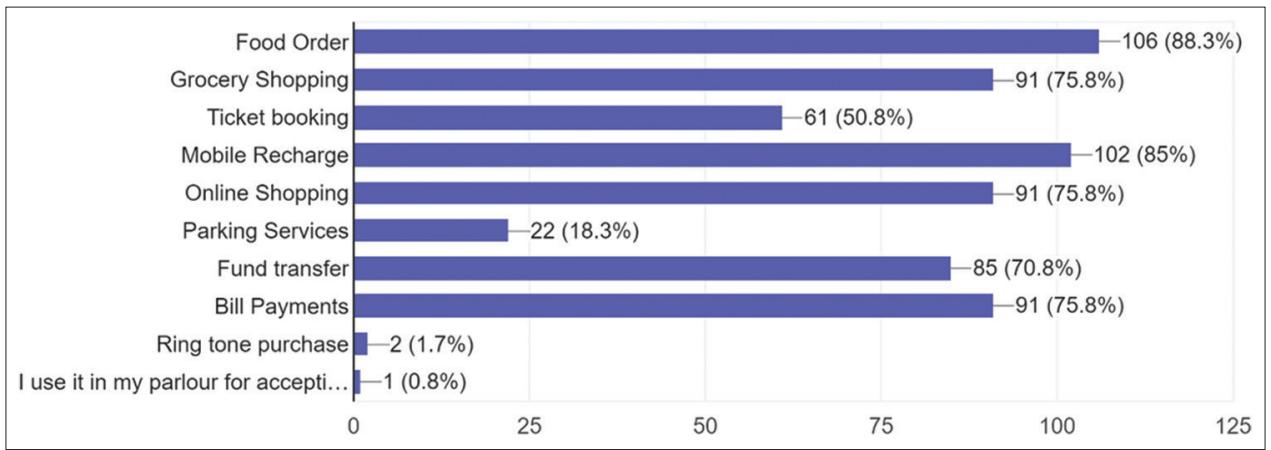

Figure 9: Type of transactions made on mobile wallets during 2020

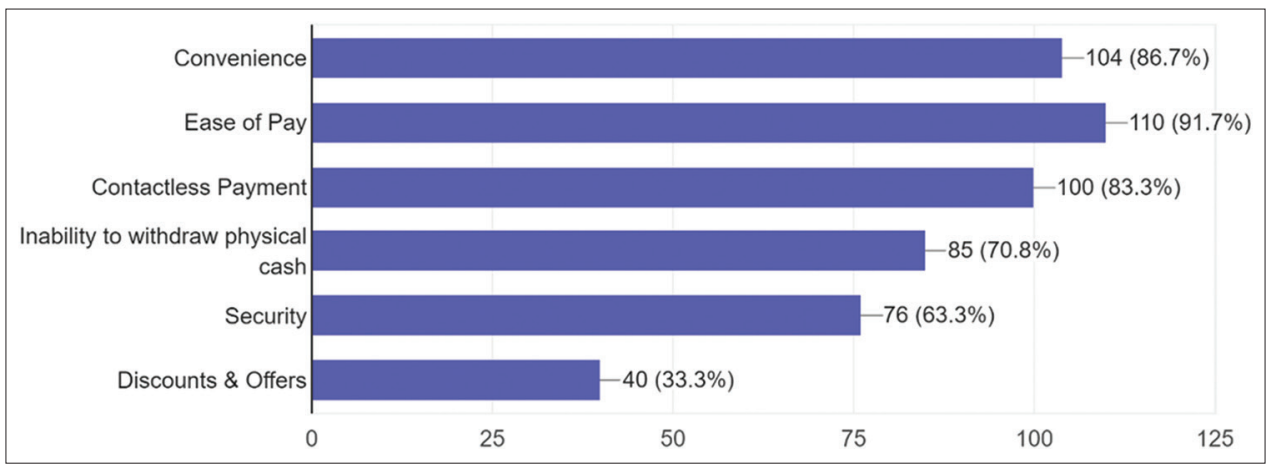

Figure 10: Reasons for usage of mobile wallets during the COVID-19 pandemic

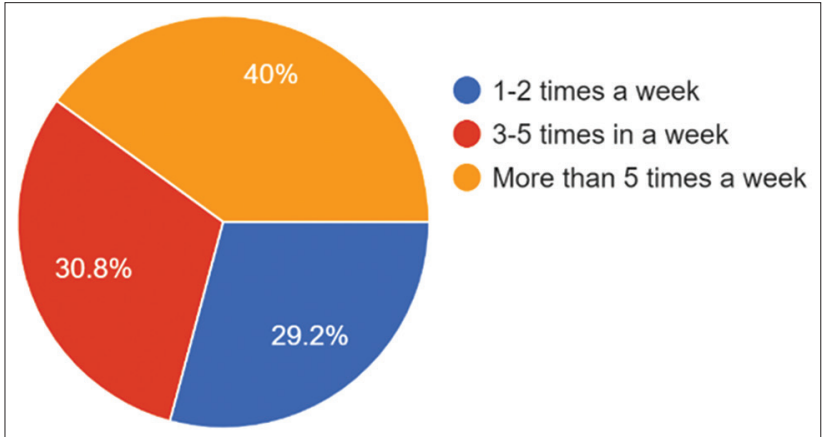

Figure 11: Usage of mobile wallets in 2020 lockdown

rated it as " $5 / 5$." The least rating given was " $3 / 5$," indicating that respondents were generally satisfied with the adaptability of mobile wallets during the pandemic.

14. Usage of mobile wallets in the future

All the respondents are completely satisfied with mobile wallets and will continue to use them into the future, which can be easily comprehended from Figure 14. This clearly indicates that usage of mobile wallets will continue to sustain even after the COVID-19 pandemic. New strategies need to be devised and implemented to sustain this surge even after the pandemic.

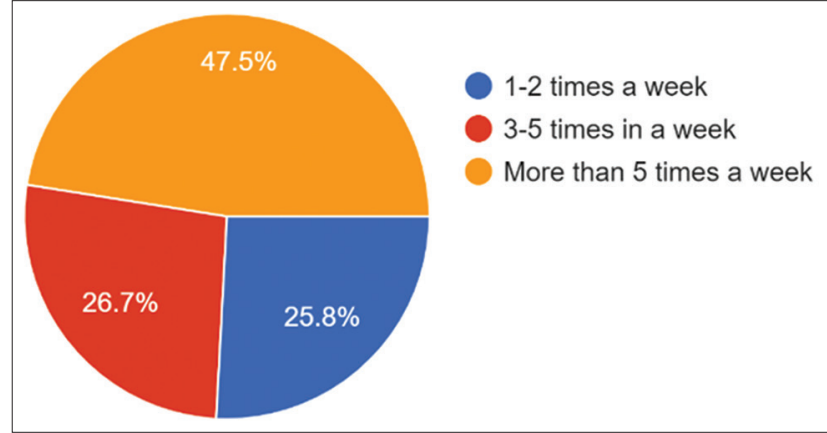

Figure 12: Usage of mobile wallets in 2021

15. Likeliness to recommend mobile wallets to others

As shown in Figure 15, about $89.2 \%$ of the respondents are extremely likely to recommend mobile wallets to someone they know, while $10.8 \%$ of the respondents are slightly likely to do so. This illustrates the level of customer confidence in mobile wallets.

\section{Testing of Hypothesis}

From the above data collection (Part A and B), the following is the hypothesis testing: 


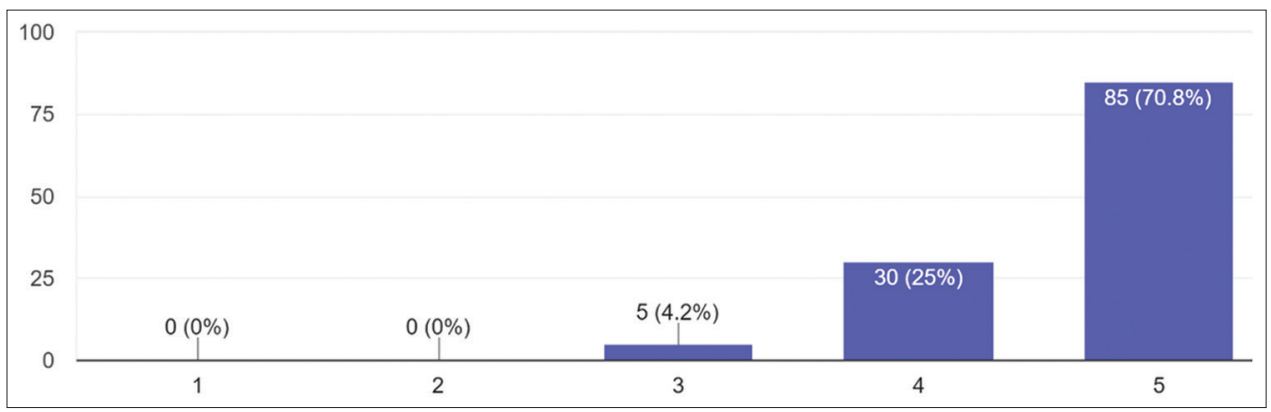

Figure 13: Adaptability of mobile wallets during the COVID-19 pandemic

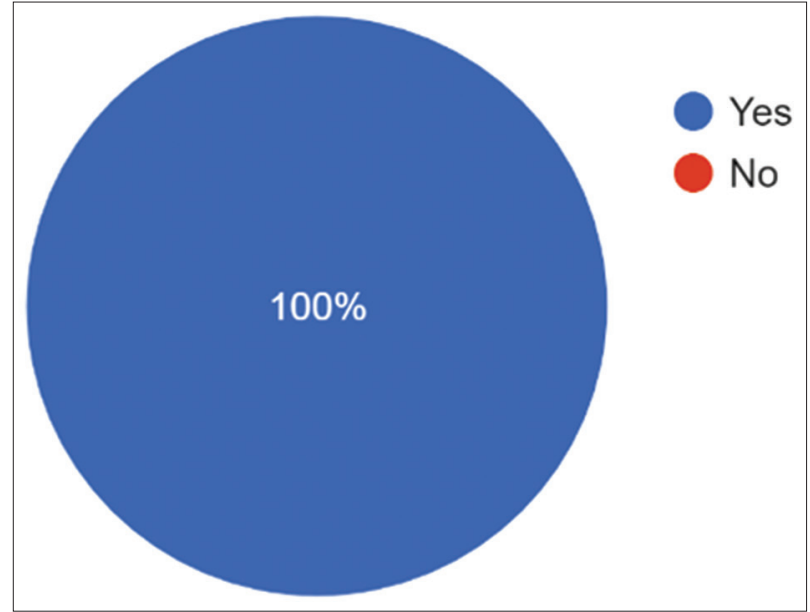

Figure 14: Usage of mobile wallets in the future

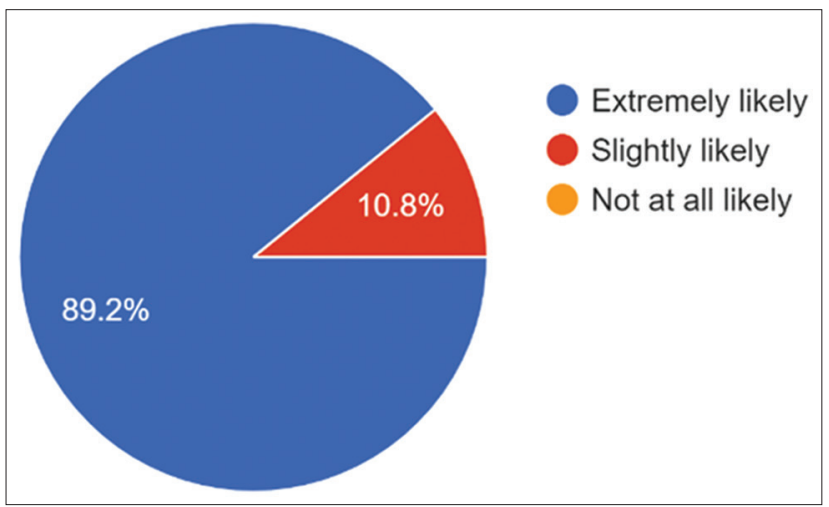

Figure 15: Likeliness to recommend mobile wallets to others

\section{Hypothesis $1\left(\mathrm{H}_{1}\right)$}

- Statement: The COVID-19 pandemic has resulted in an increase in the usage of mobile wallets in India

- Result: True
- Reason: From Part A of the data collection, from 2020 to 2021, all three applications witnessed a significant increase in the number of transactions reported. The COVID-19 pandemic has given mobile wallets a boost they could never have imagined. During the COVID19 epidemic, these applications were able to acquire a larger portion of the market and penetrate even farther

- From Part B of the data collection, the percentage of people who use mobile wallets more than 5 times each week increased from $40 \%$ in 2020 to $47.5 \%$ in 2021. This shows that since 2020 , people have been increasing their usage of mobile wallets and will continue to do so in the future

- Decision: Accepted

\section{Hypothesis $2\left(\mathrm{H}_{2}\right)$}

- Statement: The increase in usage of mobile apps in India will continue to sustain even after the COVID-19 pandemic

- Result: True

- Reason: From Part B of the data collection, each and every one of the respondents has stated that they are satisfied with mobile wallets and will continue to use them into the future. This clearly indicates that the usage of mobile wallets will continue to sustain even after the COVID-19 pandemic. New strategies need to be devised and implemented to sustain this surge even after the pandemic. About $70.8 \%$ of the respondents were extremely satisfied with the adaptability of the mobile wallets during the COVID-19 pandemic and rated it as " $5 / 5$," and $89.2 \%$ of the respondents are extremely likely to recommend mobile wallets to someone they know. This illustrates the level of customer confidence in mobile wallets. All these suggest that the increase in usage of mobile apps in India will continue to sustain even after the COVID-19 pandemic

- Decision: Accepted 


\section{BOTH THE HYPOTHESES ARE FOUND TO BE TRUE AND ARE ACCEPTED}

\section{Limitations of the Research Study}

The study is not an extensive research and hence has the following limitations:

- The primary data collected are focused only on a small sample of the total population

- The study could not include various other important factors that could have influenced the customers due to time constraints

- Does not take into consideration economic factors that affect consumer's purchasing behavior such as purchase capacity, economic slowdown, customer's taste, and preferences

- Does not take into consideration psychological factors that affect consumer's purchasing behavior like consumer's approach

- Has only considered the top three payment apps in terms of volume and users, and has not included the other apps that are used in India.

\section{Findings of the Research Study}

- The use of UPI as a payment method has increased considerably, that is, transaction volume and value have scaled up faster due to the COVID-19 as people preferred digital mode of payment more. The use of cash has seen a significant decline during the pandemic.

- Our study has been able to prove that COVID-19 pandemic has indeed resulted in an increase in the usage of mobile wallets in India. The COVID-19 pandemic has given mobile wallets a boost they could never have imagined. During the COVID-19 epidemic, these applications were able to acquire a larger portion of the market and penetrate even farther.

- GPay witnessed a decline in its market share due to the change in the UPI policy by NPCI where PhonePe took this as an advantage and rose to the dominant payment app on UPI. Paytm witnessed a slight decline during this time, but remained in the third position.

- The researchers have been successful in proving in our hypothesis testing that the usage of mobile wallets will continue to sustain even after the COVID-19 pandemic. Customers are optimistic about the future prospects of mobile wallets and are willing to recommend it to others.

\section{Suggestions from the Research Study}

- Our study provides suitable insights to the future of mobile wallets. The top reasons for the increase in usage of mobile wallets were ease of payment, convenience, and contactless payment. Mobile wallets will need to devise new plans and tactics in the future, with a focus on strengthening security to gain people's trust. To attract and retain customers, discounts and incentives must be offered as well

- Our study has focused only on the top three payment apps in terms of volume and users in India. Future studies can focus on the other apps used in India

- Future studies can focus on other factors that may affect the usage of mobile wallets such as economic factors and psychological factors.

\section{CONCLUSION}

During the COVID-19 outbreak, maintaining social distancing became a top priority among most, and so contactless transactions became the best solution for payments. Mobile wallets stepped in during this time and helped people stay safe. During the pandemic, there was a shift in people's purchasing patterns, with more people opting for mobile wallets over traditional payment methods. This study focuses on this shift and studied the relevance and increase in the usage of mobile wallets during the pandemic period. The researchers have analyzed that there were various reasons such as contactless payment, convenience, and ease of pay for the adoption of mobile wallets during this period. The study, which included only Google Pay, PhonePe, and Paytm, concluded that people are well aware of the advantages of using mobile wallets and will continue to use them even after the pandemic.

\section{CONFLICTS OF INTEREST}

The authors declare that the work submitted is an original work and is not copied from anywhere. All the articles or journals referred to have been duly cited in text and in references attached. The authors declare that they have no issued in regard to publication of the article under the Indian Journal of Commerce and Management. The authors declare that they have no known competing financial interests or personal relationships that could have appeared to influence the work reported in this paper.

\section{ACKNOWLEDGMENTS}

We are indebted to many people who helped us accomplish this research successfully. First, we thank the Principal, 
George, et al.: Study on usage and relevance of mobile wallets in India in COVID-19 pandemic

Dr. Hrishikesh Soman of Symbiosis College of Arts and Commerce, for giving us the opportunity to do the research and providing us with all necessary facilities. We thank Dr. Nilesh Waghmare, Assistant Professor at Symbiosis College of Arts and Commerce, whose support and guidance throughout the research are immeasurable; and all the faculty members of the department of accountancy, for their kind support and motivation. We thank our parents for their blessings and constant support, without which this research paper would not have seen daylight.

\section{REFERENCES}

Anandan, K., \& Mouli, S.C. (2020). Study on COVID19 lockdown's impact on digital payment system in Bangalore-a descriptive study. Brindavan Journal of Management and Computer Science, 1(1), 124-128.

Bhalla, T. (2020). E-wallet Transactions Surge Amid Covid-19, Live Mint. Retrieved from https://www. livemint.com/companies/news/digital-wallets-makea-comeback-in-covid-crisis-11596644905299.html.

Gupta, S.B., Yadav, R.K., \& Shivani, G. (2020). Study of Growing Popularity of Payment Apps in India. Vol. 82. Oakland, CA: The Mattingley Publishing Co., Inc. p16110-16119.

Jain, A., Sarupria, A., and Kothari, A. (2020). The impact of COVID-19 on E-wallet's payments in Indian economy. International Journal of Creative Research Thoughts, $8(6), 2447-2454$.

Kotecha, P. S. (2018). An empirical study of mobile wallets in India. Online Journal of Multidisciplinary Subjects Research Guru, 11(4), 605-611.

Manikandan, A. (2021). NPCI Caps Market Share for UPI Apps at 30\% of Overall Payment Volumes. The Economic Times. Retrieved from https://www. economictimes.indiatimes.com/tech/technology/npcienforces-new-market-share-rules-on-upi-for-googlepay-phonepe-paytm-others/articleshow/81701508. cms? from $=$ mdr.

News18. (2021). Paytm New Feature Allows Applying for IPOs Before Issue Opens: How to Apply for Zomato IPO. News18. Retrieved from https://www.news18. $\mathrm{com} /$ news/business/paytm-new-feature-to-book-iposbefore-issue-opens-in-market-how-to-book-zomatoipo-3952673.html.

Pakrasi, S. (2021). Paytm Launches Covid-19 Vaccine Slot Booking Feature: All You Need to Know.
Hindustan Times. Retrieved from https://www. hindustantimes.com/business/paytm-launchescovid-19-vaccine-slot-booking-feature-allyou-need-to-know-101623736527864-amp. html\#amp_ct $=1627579296883 \& a m p \_t f=F r o m \% 20$ $\% 251 \% 24$ s\&aoh $=16275784361539 \&$ csi $=1 \&$ referrer=https $\% 3 \mathrm{~A} \% 2 \mathrm{~F} \% 2 \mathrm{Fwww}$.google.com.

Praiseye, T., \& John, F. (2018). A study on consumer preference towards mobile wallet. IJRAR, 5(3), $185-189$.

PTI. (2021). Paytm Shareholders Approve Country's Biggest Public Offer Plan of Rs 16,600 Crore. Times of India. Retrieved from https://www.timesofindia. indiatimes.com/business/india-business/paytmshareholders-approve-countrys-biggest-public-offerplan-of-rs-16600-crore/articleshow/84348225.cms.

Sheth, H. (2021). PhonePe Launches a New Wallet Auto Top-up Feature. The Hindu Business Line. Retrieved from https://www.thehindubusinessline.com/moneyand-banking/phonepe-launches-a-new-wallet-autotop-up-feature/article34850649.ece.

Soni, S. (2021). UPI Ends 2020 on High Note, Scales Past Rs 4-lakh-cr Milestone in December; Volume up 70\% from Year-ago. Financial Express. Retrieved from https://www.financialexpress.com/industry/bankingfinance/upi-ends-2020-on-high-note-scales-past-rs-4lakh-cr-milestone-in-december-volume-up-70-fromyear-ago/2163173.

Surabhi (2020). Fintech: Digital Payments Got a Covid Boost in 2020. The Hindu Business Line. Retrieved from https://www.thehindubusinessline.com/ money-and-banking/digital-payments-got-a-covidboost-in-2020/article33419349.ece.

Tech Desk. (2021). Google Pay to Get New Feature, Which Will Let Users Turn Off Activity in Privacy Settings. The India Express. Retrieved from https:// www.indianexpress.com/article/technology/technews-technology/google-pay-to-get-new-featurewhich-will-let-users-turn-off-activity-in-privacysettings-7223980.

Vijai, C. (2019). Mobile wallet and its future in India. Journal of Emerging Technologies and Innovative Research, 6(5), 574-580.

ZeeBizWebTeam.(2020).PaytmBusiness KhataRegistration Leapfrogs During COVID-19 Lockdown, Zee Business. Retrieved from https://www.zeebiz.com/smallbusiness/news-paytm-business-khata-registrationleapfrogs-during-covid-19-lockdown-127316. 